\title{
Atomic force microscopy reveals microscale networks and possible symbioses among pelagic marine bacteria
}

\author{
Francesca Malfatti, Farooq Azam* \\ Marine Biology Research Division, 0202, Scripps Institution of Oceanography, University of California San Diego, \\ La Jolla, California 92093, USA
}

\begin{abstract}
Marine Bacteria and Archaea ('bacteria') interact with upper ocean productivity to fundamentally influence its biogeochemical fate with consequences for ecosystems and global climate. Most bacteria-mediated carbon cycling is due to numerically dominant free-living bacteria, but their adaptive strategies to interact with primary productivity are not fully understood. Using atomic force microscopy (AFM), we made the surprising discovery that a substantial, and variable, fraction (on average $30 \pm 17.8 \%$ with a range of 0 to $55 \%$ ) of 'free-living' bacteria in our samples from California coastal and open ocean environments were, in fact, intimately associated with other bacteria at nanometer to micrometer scales. Twenty-one to $43 \%$ of bacteria, including Synechococcus, were conjoint. Such close associations could indicate symbioses; however, they could also be antagonistic, parasitic, neutral, or accidental. Further, a substantial fraction (4 to $55 \%$ ) of bacteria was connected by pili and gels into cell-cell pairs or occurred in networks of up to 20 cells. We frequently observed nanoparticles associated with the networks, raising the question of their identity and origin (e.g. scavenged from the seawater colloid pool by the networks or produced by the bacteria within the networks). The networks occasionally contained structures that morphologically resembled coccoliths or protist scales. These may impart ballast to sinking particles if the networks coalesce to form larger, sinking, particles. Our finding of abundant bacteria-bacteria associations and possible microenvironment structuring by pelagic bacteria offers a novel context for bacterial ecology and diversity and models of ocean productivity and elemental cycling.
\end{abstract}

KEY WORDS: Carbon cycling $\cdot$ Attached bacteria · Free-living bacteria - Synechococcus-bacteria association - Bacteria-bacteria association · Microscale biogeochemistry

Resale or republication not permitted without written consent of the publisher

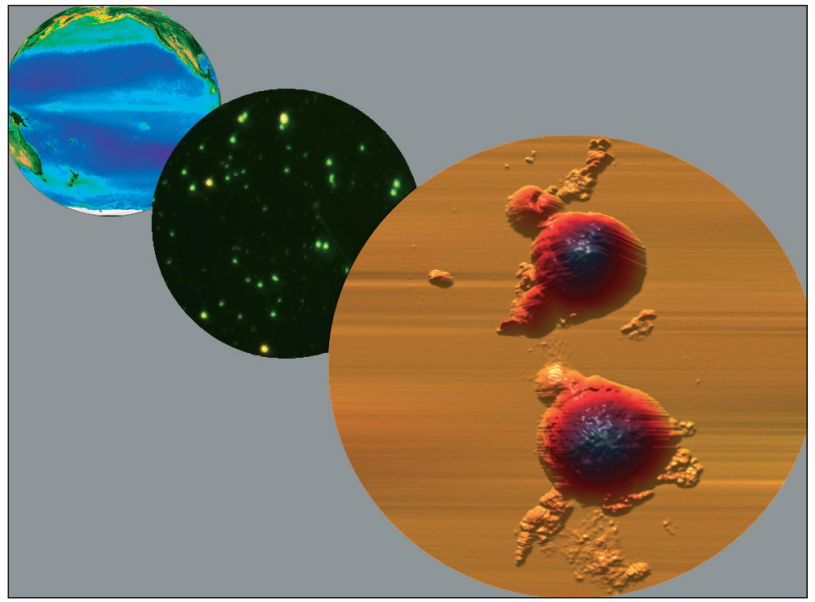

Microscale exploration of the sea. Bottom right: Atomic force microscope image showing intimate associations among heterotrophic bacteria and Synechococcus cells, a major primary producers in the ocean. Center: Epifluorescence microscopy image of heterotrophic bacteria and Synechoccus cells. Top left: Image selected from SeaWiFS Biosphere Globes (http://oceancolor.gsfc.nasa.gov/SeaWiFS/) showing satellitebased view of an expanse of the ocean.

Authors of the image composition: Francesca Malfatti, Ty J. Samo, Farooq Azam

\section{INTRODUCTION}

Bacteria and Archaea comprise the majority of marine biomass, show high biodiversity, and mediate over one half of the global ocean carbon cycling (Pomeroy et al. 2007). Their actions on the upper ocean primary productivity (PP) regulate system respiration and carbon flux to the ocean's interior (del Giorgio \& Williams 2005, Nagata 2008). Therefore, the nature and the strength of bacteria-PP coupling is an important variable in predicting the response of the ocean's biogeochemical state to ecosystem perturbations (Azam \& Malfatti 2007). Since most bacteria-mediated carbon flux is due to free-living bacteria, a long-standing 
question is how the free-living heterotrophic bacteria achieve tight coupling with (largely particulate) PP (Ducklow 2002, Nagata 2008). An emergent view is that a variety of physiological and trophic interactions transform a substantial fraction of productivity into a size continuum of organic matter from monomers to colloids to particles and aggregates (Koike et al. 1990, Azam 1998, Chin et al. 1998, Verdugo et al. 2004). All of these organic matter phases would then be direct or potential (e.g. after enzymatic attack by bacteria) substrates for the free-living bacteria.

This departure from the traditional dichotomy of particle-attached versus free-living bacteria suggests that assemblages of free-living bacteria interacting with an organic matter continuum create a mosaic of biogeochemical activity hotspots in seemingly homogeneous seawater. It also emphasizes the significance of the bacterial cell surface, the largest biotic surface in the ocean (Williams 2005), for the interactions with organic matter pool to transform its biogeochemical behavior. In view of the great physicochemical diversity of the organic matter phases with which bacteria interact in seawater, we considered that high resolution imaging (Dufrene 2008b) could provide additional insights into the interactions between bacteria and organic matter.

Electron microscopy (transmission, TEM; and scanning, SEM) has long been used to investigate marine bacteria and their surface layers and appendages potentially involved in interactions with the environment. Studies have illustrated in detail the variety of sizes, shapes, and surface morphologies of environmental bacteria as well as their occurrence as freeliving (planktonic) or particle-attached bacteria (Sieburth 1975, Costerton et al. 1981, Johnson \& Sieburth 1982, Beveridge \& Graham 1991). Extensive TEM and SEM images of pelagic bacteria including cyanobacteria have been published by Johnson \& Sieburth (1982). Heissenberger et al. (1996a, and references therein) addressed bacterial interactions in natural seawater samples by TEM, using a water-soluble embedding resin, Nanoplast ${ }^{\mathrm{R}}$, that preserves capsules and mucus layers in their hydrated forms (Lienemann et al. 1998). They showed the presence of mucus and bacterial capsular material bridging bacteria with diatom detritus as well as other bacteria. There is also recent literature based on genomic inferences that pelagic bacteria express surface polysaccharides and proteins for interaction with particles and organisms, and these data have been interpreted in terms of attached and freeliving life styles of bacteria (Moran et al. 2007). However, it is recognized that the 'real life' interactions of bacteria in the ocean water are likely to be more complex. Ideally, one would wish to observe the in situ microbial interactions with the organic matter continuum in real time. However, given the current technical challenges involved, multiple constraints with imaging, tracer and genomic approaches could begin to progressively sharpen our understanding of the interactions and their mechanistic bases. We considered that exploration at the nanometer to micrometer scale of physical interactions of bacteria and their in situ environment would provide biogeochemical insights and generate new hypotheses.

Since its invention (Binnig \& Quate 1986), atomic force microscopy (AFM) has evolved in instrumentation and sample preparation. It now offers the capability to generate sub-nanometer resolution images of biological samples, including bacterial surface structures (Dufrene 2008b). AFM enables high resolution comparable to electron microscopy but without the need for embedding or metal coating. AFM is a scanning-proximity probe microscope. It provides information on the local properties of the sample, such as topography, viscoelasticity, electrical and magnetic forces, and chemical bonding. Further, AFM can enable physiochemical interrogation at the nanometer to micrometer scale of living specimens (Dufrene 2008a).

In our case, an additional advantage was that we could concurrently use AFM and epifluorescence microscopy (EFM; Mangold et al. 2008) in order e.g. to identify a cell as a cyanobacterium before AFM imaging. Such prior interrogation, not intuitive in TEM or SEM, is valuable in studying microbial interactions. The use of AFM in microbial oceanography is recent and limited. Pioneering studies by Santschi et al. (1998), Svetlicic et al. (2005), and Balnois \& Wilkinson (2002) addressed questions on the nanoscale structure of marine gels and fibrils. The application of AFM in microbial oceanography was pioneered recently. Nishino et al. (2004) used it to size marine bacteria, and Seo et al. (2007) tested whether bacteria capture nanoparticles from seawater. Because so few studies have been conducted in the marine system, it is both an exciting opportunity to explore seawater with AFM and a challenge, due to a lack of current constraints, to interpret images for ecological and biogeochemical insights. However, there is considerable literature on AFM imaging of laboratory cultures of bacteria, and we can draw upon this literature for interpretation (Dufrene 2008a,b).

The aim of the present study was to image pelagic marine bacteria at high resolution in order to investigate how they interact with other bacteria and with the organic matter continuum. Our AFM imaging of whole seawater samples surprisingly revealed that many 'free' bacteria were in fact intimately associated with other bacteria, either conjoint or connected by fibrils into pairs or networks. Provided our images substantially reflect the natural state, these intimate associations may be adaptive for pelagic bacteria and cyanobacteria, with biogeochemical implications. 
Table 1. Sampling locations, dates, and environmental variables. Heterotrophic bacteria were analyzed at each station; Synechococcus was analyzed 5 times at the Scripps Institute of Oceanography (SIO)/coastal site and once at the California Current Ecosystem (CCE)/offshore site at $53 \mathrm{~m}$ depth

\begin{tabular}{|c|c|c|c|c|c|c|c|}
\hline Site & Station & Coordinates & $\begin{array}{l}\text { Depth } \\
\text { (m) }\end{array}$ & $\begin{array}{l}\text { Chl a } \\
\left(\mu \mathrm{g} \mathrm{l}^{-1}\right)\end{array}$ & $\begin{array}{c}\text { Temperature } \\
\left({ }^{\circ} \mathrm{C}\right)\end{array}$ & Period/Date & $\begin{array}{l}\text { Sampling } \\
\text { frequency }\end{array}$ \\
\hline Coastal & $\begin{array}{c}\text { SIO } \\
\text { EK } \\
\text { Sorcerer II }\end{array}$ & $\begin{array}{l}32.867^{\circ} \mathrm{N}, 117.257^{\circ} \mathrm{W} \\
32.523^{\circ} \mathrm{N}, 117.165^{\circ} \mathrm{W} \\
32.465^{\circ} \mathrm{N}, 117.241^{\circ} \mathrm{W}\end{array}$ & $\begin{array}{c}1 \\
1 \\
30\end{array}$ & $\begin{array}{c}0.38-14.7 \\
- \\
13\end{array}$ & $\begin{array}{c}15.3-24.4 \\
18 \\
20\end{array}$ & $\begin{array}{l}\text { Apr-Aug } 08 \\
15 \text { May } 08 \\
10 \text { Sep } 08\end{array}$ & $\begin{array}{c}16 \\
1 \\
1\end{array}$ \\
\hline $\mathrm{CCE}$ & $\begin{array}{l}164 \\
206\end{array}$ & $\begin{array}{l}35.358^{\circ} \mathrm{N}, 121.075^{\circ} \mathrm{W} \\
33.659^{\circ} \mathrm{N}, 123.133^{\circ} \mathrm{W}\end{array}$ & $\begin{array}{c}7 \\
15(53)\end{array}$ & $\begin{array}{l}0.18 \\
1.18\end{array}$ & $\begin{array}{l}12.4 \\
14.4\end{array}$ & $\begin{array}{l}7 \text { Apr } 07 \\
9 \text { Apr } 07\end{array}$ & $\begin{array}{l}1 \\
1\end{array}$ \\
\hline Antarctica & $\begin{array}{l}178 \\
197\end{array}$ & $\begin{array}{l}60.370^{\circ} \mathrm{S}, 54.318^{\circ} \mathrm{W} \\
60.450^{\circ} \mathrm{S}, 58.225^{\circ} \mathrm{W}\end{array}$ & $\begin{array}{l}10 \\
35\end{array}$ & $\begin{array}{l}0.11 \\
0.14\end{array}$ & $\begin{array}{l}-0.96 \\
-0.66\end{array}$ & $\begin{array}{l}21 \mathrm{Jul} 06 \\
25 \mathrm{Jul} 06\end{array}$ & $\begin{array}{l}1 \\
1\end{array}$ \\
\hline
\end{tabular}

\section{MATERIALS AND METHODS}

Sampling. Seawater samples for AFM were taken from 3 different environments designated 'coastal,' 'CCE' (California Current System, offshore locations), and 'Antarctic' (Table 1). Most coastal samples were collected at the surface off the pier of the Scripps Institution of Oceanography (SIO). This location has been sampled for $\sim 90$ yr for physical, biological, and biogeochemical parameters. A comparably extensive ( 60 yr) time-series data set has also been collected from the CCE (CalCOFI data set), and we analyzed seawater from 2 CCE stations. Time-series analysis indicates strong coherence of biogeochemical variability at SIO and CCE (McGowan et al. 1998, Kim 2008). Two other coastal sites, EK and Sorcerer II, were sampled once. Our extensive sampling at the SIO pier together with limited sampling in other coastal and CCE waters may be expected to include biogeochemical variability applicable to a geographically broad area. CCE samples were taken during Cycle 1 and Cycle 2 of a CCELTER cruise in April 2007 at Stns 164 and 206 (http://cce.lternet.edu/data/cruises/cce-p0704/). Antarctic samples were collected during austral winter 2006 at Stns 178 and 197 during the BWZ cruise in the Drake Passage (coordinates in Table 1).

Chlorophyll a (chl a) was measured fluorometrically in discrete samples after extraction (Holm-Hansen \& Riemann 1978) and by an in vivo chlorophyll sensor. Seawater temperature (CTD) data were retrieved from the Southern California Coastal Ocean Observing System (SCCOOS) data archive website (www.sccoos.org supported by NOAA), from the CCE-LTER data archive website (http://oceaninformatics.ucsd.edu/ datazoo/data supported by the Division of Ocean Sciences, NSF Grant OCE-0417616), and from the BWZ II website (http://spg.ucsd.edu, supported by NSF Grant ANT- 0444134).

AFM sample preparation. Drop-deposition: Seawater samples were fixed with $0.02 \mu \mathrm{m}$ filtered formaldehyde solution (Nishino et al. 2004) and stored for $1 \mathrm{~h}$ at $4^{\circ} \mathrm{C}$ before spotting on mica. Fixation was necessary to prevent cell lysis. A high quality mica disc (no. 50; Ted Pella; no. 71856-01, Electron Microscopy Sciences) was attached to a clean glass slide by double-sided sticky tape (Veeco Instruments). A 50 to $100 \mu \mathrm{l}$ drop was deposited on a freshly cleaved mica disc (Amro et al. 2000, Balnois \& Wilkinson 2002), let dry at $50^{\circ} \mathrm{C}$, and rinsed with autoclaved HPLC-grade water. We tested different rinse waters for particle background: Milli-Q water (Millipore), Milli-Q water filtered through a $100 \mathrm{kDa}$ centrifugal ultrafiltration cartridge (Microcon; Millipore), and HPLC-grade water (Fisher Scientific). HPLC-grade water had the lowest particle level, so it was chosen as rinse water. We tested whether formalin fixation or drying temperature (room temperature versus $50^{\circ} \mathrm{C}$ ) affected the appearance of organic matter structures. We did not notice any obvious qualitative treatment-dependent differences in the general appearance of organic matter in AFM images. Further, we determined the effect of formaldehyde fixation on the appearance of the surface of bacteria (Vibrio cholerae strain N16961). The unfixed cells appeared smooth, whereas the fixed cells presented a rough surface, in agreement with previous AFM studies (Vadillo-Rodriguez et al. 2008, and references therein).

Filtration and filter-transfer-freeze to mica: CCE and Antarctic cruise samples had been collected on polycarbonate membranes (Isopore; Millipore). The roughness of Isopore filters is too high, $\sim 3 \mathrm{~nm}$, for visualization of finer fibrils and architecture. Mica has a very low roughness of $<0.2 \mathrm{~nm}$. We transferred the filtered cells and particulate matter onto mica using the Filter-Transfer-Freeze (FTF) technique (Hewes \& Holm-Hansen 1983). Transfer efficiency of FTF is known to be high (82 to $95 \%$ ) for phytoplankton but it not known for bacteria or nanometer-sized material; therefore, the imaged bacteria-associated material in samples treated by FTF would represent minimum 
estimates. Seawater samples were collected with Niskin bottles. Samples were fixed with $0.2 \mu \mathrm{m}$ filtered formaldehyde ( $2 \%$ final). They were vacuum filtered $(-16 \mathrm{kPa})$ onto $0.2 \mu \mathrm{m}$ white polycarbonate filters and rinsed with $0.2 \mu \mathrm{m}$ filtered autoclaved Milli-Q water, and the filters were stored frozen at $-20^{\circ} \mathrm{C}$ until transferred to mica. A freshly cleaved mica disc was attached to a clean glass slide, and the back of the slide was flash-frozen with a brief spray of tetrafluoroethane (Decon Lab). One filter quadrant was placed face down on the chilled mica for $10 \mathrm{~s}$ and then peeled off. The mica was let air-dry in a Petri dish and was then washed with autoclaved HPLC water. To test whether thawing and freezing might introduce artifacts, we compared drop-deposited samples to FTF samples. We noticed no qualitative sample-preparation difference, as cell surface architecture, conjoint pairs, and networks were all present in both treatments. A caveat is that we had to use difference subsamples (of the same seawater samples), so we could not image the same cells prepared by the 2 methods.

AFM imaging. AFM measures the inter-atomic van del Waals forces between the scanning probe and the sample surface. The cantilever carries at its end a sharp tip, or probe, that is rastered over the sample, and the cantilever movement is monitored via interferometry by a laser-photodetector system. The cantilever continuously bends due to the attraction-repulsion forces between tip and sample, thereby creating a high-resolution topographic map of the specimen surface. AFM imaging was performed in our laboratory with an MFP-3D (Asylum Research) mounted on an inverted epifluorescence microscope (Olympus IX 51). Images were acquired in AC mode in air with a silicon nitride cantilever AC160TS (Olympus, $\mathrm{k}=42 \mathrm{~N} \mathrm{~m}^{-1}$; tetrahedral shape). Scan rates were 0.8 to $1 \mathrm{~Hz}$. Image resolution was $256 \times 256$ or $512 \times 512$. We recorded trace and retrace of height, amplitude, phase, and $Z$ ( $Z$ = height) sensor channels. Topography images were processed with Planfit and Flatten functions. Bacteria and organic matter were sized with the measuring tool part of the Igor Pro 6.03A MFP3D 070111+830 software. While AFM dilates the object shape because of tip geometry, progress in nanotechnology to build super-sharp cantilevers $(<10 \mathrm{~nm}$ apex radius, used in this study) and deconvolution algorithms (Ritter et al. 2002) now essentially cancel out the tip effect.

EFM. We used EFM prior to AFM imaging in order to identify autofluorescent Synechococcus and SYBRGold ${ }^{\circledR}$-stained heterotrophic bacteria. A freshly cleaved mica disc, reduced in thickness (to enable EFM through it) with a clean razor blade, was affixed on a microscopy slide using double-sided sticky tape. (Note that the tape is strongly autofluorescent, so it must be placed at the edges of the mica disc to prevent background fluorescence.) Seawater was spotted on mica, dried, and washed with HPLC water, then stained with SYBRGold ${ }^{\circledR}$ (Invitrogen; $5 \times$ final) for 15 min in the dark. On mica, we identified Synechococcus cells at $400 \times$ magnification based on phycoerythrin autofluorescence using a Chroma filter set 51006 (see Fig. 4g) as well as heterotrophic bacteria based on SYBRGold ${ }^{\circledR}$ staining using an Olympus filter UMNIBR. We then acquired AFM scans of the EFMidentified Synechococcus cells on mica. Our AFM scan-head interrogates from the top of the sample, so fluorescence microscopy must be done through the slide (plus mica). The depth of focus of our microscope objective limited us to the use of a $40 \times$ objective.

\section{RESULTS AND DISCUSSION}

\section{Cell surface architecture}

Although we studied whole seawater samples, our focus was on bacteria; other organisms and organic matter were considered only in the context of their interactions with bacteria. We imaged over 500 bacteria, including Synechococcus, and any interacting

Table 2. Atomic force microscopy (AFM) data summary. Data are shown for heterotrophic bacteria and Synechococcus cells. Percent of total cell abundance displaying surface architecture, conjoint cells, or cells in networks are shown. Total cell abundance was determined by epifluorescence microscopy (EFM). CCE: California Current System/offshore stations

\begin{tabular}{|c|c|c|c|c|c|}
\hline Site & $\begin{array}{c}\text { Cell abundance } \\
\text { by EFM }\end{array}$ & $\begin{array}{c}\text { No. of cells } \\
\text { imaged by AFM }\end{array}$ & $\begin{array}{l}\text { Surface architecture } \\
\text { (\% cells imaged) }\end{array}$ & $\begin{array}{l}\text { Conjoint cells } \\
\text { (\% cells imaged) }\end{array}$ & $\begin{array}{c}\text { Bacteria in networks } \\
(\% \text { cells imaged })\end{array}$ \\
\hline Heterotrophic bacteria & $\left(10^{9}\right.$ cells $\left.^{-1}\right)$ & & & & \\
\hline Coastal & $0.22-3.14$ & 321 & 85 & 21 & 26 \\
\hline CCE & $1.22 ; 0.83$ & 107 & 74 & 43 & 37 \\
\hline Antarctica & $0.19 ; 0.11$ & 24 & 29 & 38 & 0 \\
\hline Synechococcus cells & $\left(10^{8}\right.$ cells $\left.^{-1}\right)$ & & & & \\
\hline Coastal & $0.13-1.15$ & 85 & 65 & 42 & 55 \\
\hline $\mathrm{CCE}$ & $0.13 ; 0.11$ & 50 & 28 & 42 & 4 \\
\hline
\end{tabular}


material in seawater samples from coastal and offshore California, CCE (California Current System), and Antarctica (Table 2). The majority of bacteria in the natural assemblages displayed surface architecture, and this could be relevant to their ecophysiology and interactions with organic matter. Combining all data for each sampling region, $85 \%$ of bacteria in coastal, $74 \%$ in $\mathrm{CCE}$, and $29 \%$ in Antarctic samples displayed distinct cell surface architectures. These were highly variable in dimensions and patterns and could be interpreted as capsule (Stukalov et al. 2008), pili, gel matrix (Svetlicic et al. 2005), and nanogels (Verdugo et al. 2004) (Fig.1a-d). Pili were 6 to $56 \mathrm{~nm}$ thick and 0.1 to $1.9 \mathrm{~nm}$ tall. We recognize that the surface architec- ture was likely affected by sample fixation and drying, e.g. width may have increased and height may have decreased. Further, we cannot rule out that some of the nanometer-sized spherical objects that we here call nanogels and colloids (Fig. 1b,d) are artifacts of sample preparation. However, the spherical objects in our images are comparable in shapes and size ranges of natural colloids in previous AFM and TEM studies (Leppard et al. 1997, Santschi et al. 1998, Balnois \& Wilkinson 2002, De Momi \& Lead 2008).

Pili and gel matrices extended 0.1 to $6 \mu \mathrm{m}$ from cell surfaces. These dimensions could greatly increase the interaction volume of bacteria (e.g. Fig. 1a,c). In Fig. 1a, the coccoid cell has a diameter of $336 \mathrm{~nm}$, biovol-

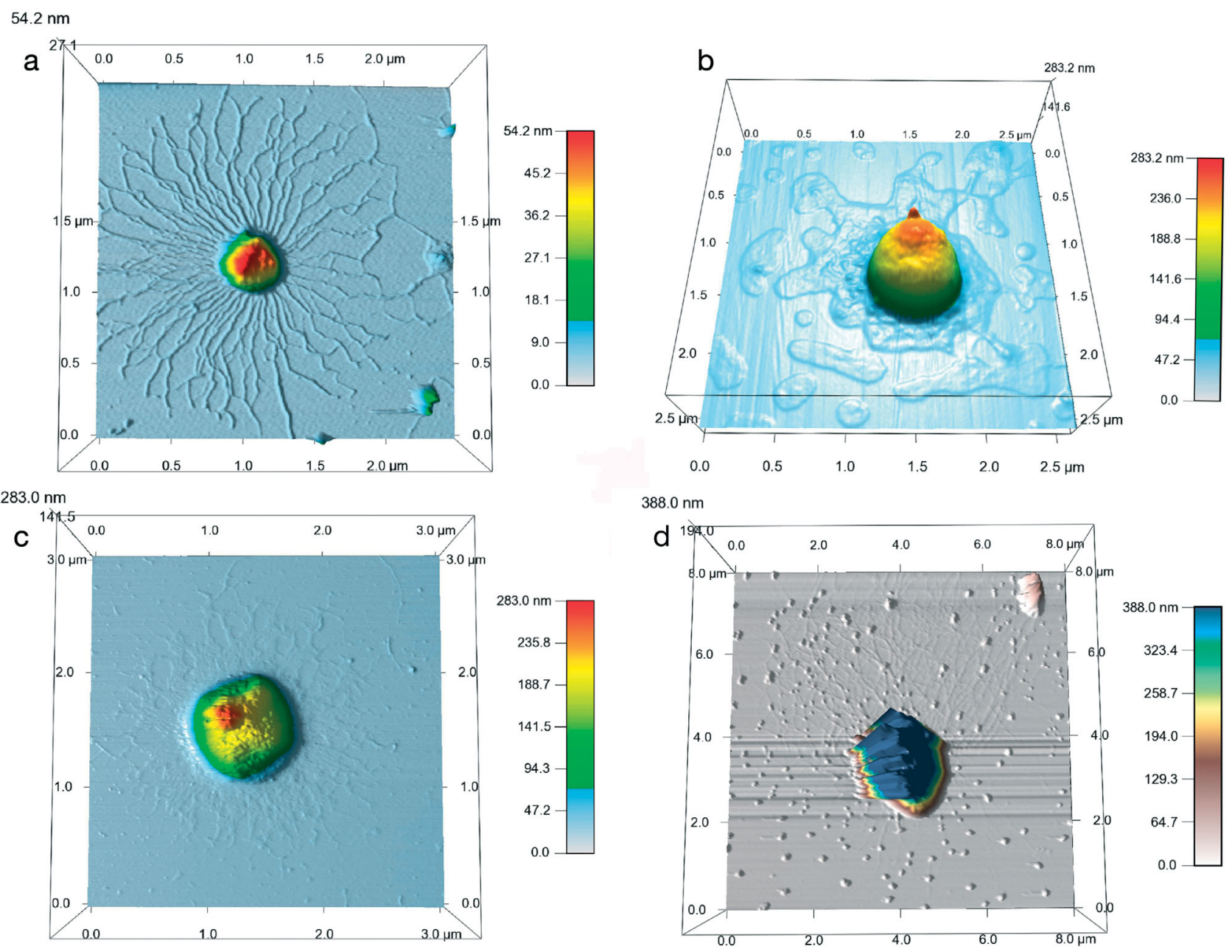

Fig. 1. Atomic force microscopy (AFM) topographic images of bacteria and Synechococcus cell surface architecture. Seawater samples were collected from a coastal site, at the Scripps Institution of Oceanography (SIO) station, in May and July 2008 (see Table 1). The height, $Z$, can be read as color on the color-coded scale or as number on the $z$-axis. (a) Coccoid (diameter $=307 \mathrm{~nm}$, $Z=54 \mathrm{~nm}$ ), surrounded by extensive pili ( 0.8 to $1 \mu \mathrm{m}$ long). (b) Coccoid $(Z=203 \mathrm{~nm}$ ) with extensive capsule and gel matrix with height range of 1 to $4 \mathrm{~nm}$. (c) Synechococcus cell $(Z=259 \mathrm{~nm})$ with elaborate architecture and tightly knit fibrils in the range of 480-800 $\mathrm{nm}$ in length. (d) Synechococcus cell $(Z=732 \mathrm{~nm})$ with intricate asymmetrical architecture $14.5 \mu \mathrm{m}$ long, on the upper end. (The architecture extends beyond the picture frame.) Cell height is purposely flattened, with loss of detail, to highlight the architecture that has a height range of 200 to $400 \mathrm{pm}$. Nanometer size particles in the range of 50 to $300 \mathrm{~nm}$ are highly abundant and associated with fibrils 
ume of $0.02 \mu \mathrm{m}^{3}$, and area of $0.089 \mu^{2}$, but including the surface architecture would increase the volume to $6.12{\mu \mathrm{m}^{3}}^{3}$ and the area to $9.9{\mu \mathrm{m}^{2}}^{2}$, i.e. $~ 300 \times$ for the volume and $\sim 100 \times$ for the area. Synechococcus sp. identified by phycoerythrin autofluorescence (see Fig. 4f,g) displayed configurations ranging from unarticulated tight capsules to elaborate and extensive architectures. These features were observed in $65 \%$ and $28 \%$ of Synechococcus cells, respectively, in coastal and CCE (offshore) samples (Fig. 1C,d). The Synechococcus cells could also extend their sphere of influence, e.g. the cell in Fig. 1c has a volume of $0.38 \mu^{3}$, but including the surface architecture increases it to $6.6 \mu \mathrm{m}^{3}$ or $\sim 17 \times$. While the validity of this calculation assumes volume conservation during sample processing, it nonetheless highlights the need to further study the significance of bacterial surface architecture and its variability in influencing the surface area for interaction with organic matter and the volume for organic matter processing. It would also be interesting to test whether such increases in effective cell volume could reduce size-selective grazing pressure by smaller protists, and possibly increase grazing pressure by larger protists.

The presence of bacterial surface architecture is well documented in bacterial physiology, and it has also been reported for marine bacteria (Nishino et al. 2004). The diversity of surface architecture among marine bacteria could reflect genetic diversity, e.g. genes for lipopolysaccharide (LPS), pili, and surface proteins. For instance, marine Synechococcus use a unique mode of motility involving the interaction of specific cell surface proteins with the environment (McCarren et al. 2005, Palenik et al. 2006). The differences in surface architecture could also reflect different physiological states or microspatial environmental variability (Moran et al. 2007, González et al. 2008).

\section{Conjoint bacteria (including Synechococcus)}

A remarkable finding was that in most seawater samples, a substantial fraction of bacteria, including Synechococcus, occurred conjoint as bacteria-bacteria (i.e. heterotrophic bacteria conjoint with heterotrophic bacteria) or Synechococcus-bacteria associations (Fig. 2, Table 2). Conjoint heterotrophic bacteria were detectable in all but 2 seawater samples (16 out of 18 coastal, 2 out of 2 CCE (offshore), and 2 out of 2 Antarctic samples). Forty-two percent of Synechococcus were conjoint with 1 or more heterotrophic bacteria in coastal and CCE (offshore) samples (Table 2). Most partners were morphologically dissimilar, so they might be phylogenetically distinct, e.g. some cells were diminutive in relation to their partners (e.g. Fig. 2b,d).
Using TEM, Heissenberger et al. (1996a,b) showed bacteria associated with phytoplankton and other bacteria by capsular envelopes and fibrillar exopolymers. However, extensive EFM studies of seawater samples over the last 3 decades missed such abundant associations. The conjoint pairs of heterotrophic bacteria in our study might have gone undetected due to the limitation of the resolving power of EFM. In AFM, we frequently observed the conjoint cells to be of different sizes, so the smaller cell might be missed in EFM (Fig. 3). The Synechococcus-heterotrophic bacteria association can be resolved by EFM, but it is critical to use optimal dye and filter sets. Staining with SYBR ${ }^{\circledR}$ dyes (Invitrogen) provides the clearest images. When using DAPI as a fluorophore, Synechococcus appears as a grey-reddish shadow and may be missed by untrained observers. In this set-up, the observer needs to sequentially switch between filters to detect DAPI and the chlorophyll signal.

We considered that conjoint bacteria could be artifacts of sample processing (e.g. free cells falling randomly in close proximity). We therefore filtered $0.2 \mathrm{ml}$ or $2 \mathrm{ml}$ seawater on $0.22 \mu \mathrm{m}$ Isopore filters and counted at the EFM over 200 Synechococcus cells in random fields to determine the percentage of Synechococcusheterotrophic associations. Synechococcus-heterotrophic partners accounted for $17 \%(37 / 209)$ and $15 \%$ $(30 / 200)$ in $2 \mathrm{ml}$ and $0.2 \mathrm{ml}$, respectively. The observation that the percentage of Synechococcus in Synechococcus-heterotroph associations remained essentially unchanged by a 10 -fold change in cell concentration on the filter supports that the associations were not significantly affected by random co-localization on the filter.

We further considered that conjoint bacteria could be an artifact of bacteria in close proximity being brought together as the sample dried. We tested this in the case of Synechococcus-heterotrophic bacteria associations (which we could visualize in filtered samples by EFM). Seawater from the coastal site (SIO pier) was fixed with $2 \%$ formaldehyde solution, and $5 \mathrm{ml}$ of sample were filtered through a $0.2 \mu \mathrm{m}$-pore-size black polycarbonate filter. To keep the filter wet, we mounted the polycarbonate filter on a slide with the GF/F backing filter underneath and placed 2 filtered-seawater-soaked GF/F filters adjacent to it. We then covered the slide with a 24 $\times 60 \mathrm{~mm}$ coverglass. In this set-up, the polycarbonate filter remained wet during the observations since during EFM we could see some bacteria and Synechococcus floating above the filter in liquid. Of the 273 Synechococcus cells examined, we found 27 to be conjoint with heterotrophic bacteria. A parallel $5 \mathrm{ml}$ sample was prepared by the standard dry-filter protocol, and it showed $8.1 \%$ Synechococcus cells to be conjoint with heterotrophic bacteria. This experiment did not support 

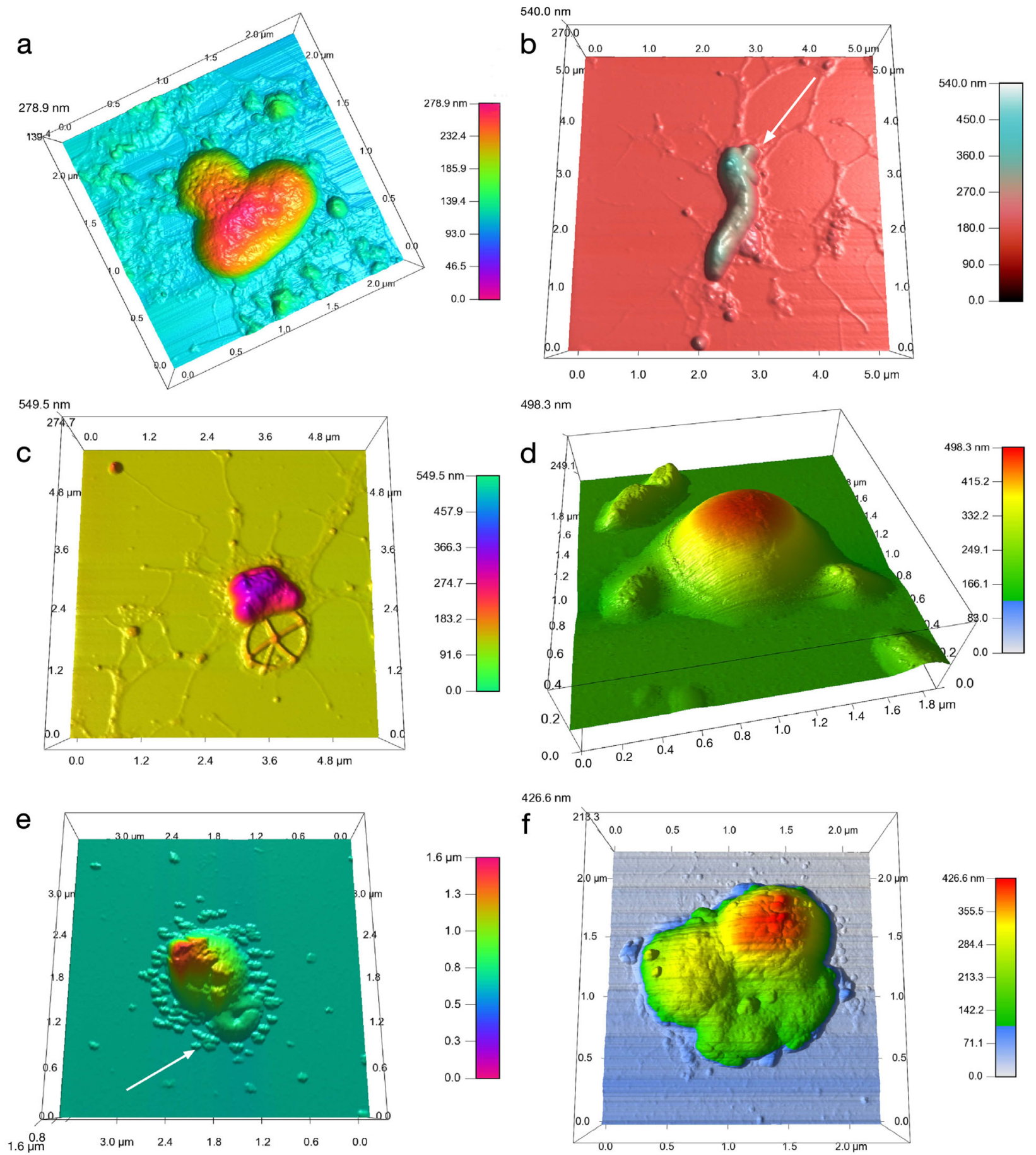

Fig. 2. Atomic force microscopy (AFM) topographic images of conjoint bacteria and Synechococcus cell. Seawater samples were collected from a coastal site (SIO) in May 2008 (see Table 1). The height, $Z$, can be read as color on the color-coded scale or as number on the $z$-axis. (a) Coccoid cell $(Z=130 \mathrm{~nm})$ and a larger $\operatorname{rod}(Z=144 \mathrm{~nm})$ are intimately conjoint. Nanometer-sized particles (green) in the range of 70 to $270 \mathrm{~nm}$ are present in the cell matrix. (b) Conjoint pair of heterotrophic bacteria (HB). The long S-shaped cell $(Z=175 \mathrm{~nm}$ ) embraces the tiny C-shaped cell (arrow; $Z=122 \mathrm{~nm}$ ). The conjoint pair is surrounded by gel architecture with nanometer-sized particles in the range of 30 to $230 \mathrm{~nm}$. (c) Conjoint pair of rods. The upper and the lower cell are, respectively, $194 \mathrm{~nm}$ and $179 \mathrm{~nm}$ tall. The cells are surrounded by a gel matrix. A coccolith (diameter = $1.12 \mu \mathrm{m}$ ) and nanometersized particles, in the range of 45 to $280 \mathrm{~nm}$, are present in the gel matrix. (d) Synechococcus cell (diameter $=840 \mathrm{~nm}, Z=374 \mathrm{~nm}$ ) conjoint with 2 diminutive bacteria, embedded in mucus layer; 3 other HB are not conjoint, 2 in the upper part and 1 in the lower part of the picture. The left conjoint HB is $174 \mathrm{~nm}$ long, $143 \mathrm{~nm}$ wide, and $42 \mathrm{~nm}$ tall; the right conjoint HB is $211 \mathrm{~nm}$ long, $133 \mathrm{~nm}$ wide, and $43 \mathrm{~nm}$ tall. (e) Synechococcus cell $(Z=712 \mathrm{~nm})$ associated with a C-shaped cell $(Z=115 \mathrm{~nm}$; arrow) and surrounded by numerous particles in the range of 50 to $200 \mathrm{~nm}$. (f) Dividing Synechococcus cell (top cell), $427 \mathrm{~nm}$ tall, is conjoint with a $1.2 \mu \mathrm{m}$ long and $119 \mathrm{~nm}$ tall HB. The conjoint pair is surrounded by a thin capsule and nanometer-sized particles in the range of 20 to $80 \mathrm{~nm}$ 
Table 3. Effect of sample drying on determination of frequency of Synechococcus cells conjoint with heterotrophic bacteria. Seawater samples were obtained from the coastal site (SIO; see Table 1). Conjoint frequency was determined on polycarbonate filters by epifluorescence microscopy. Also shown is a comparison of conjoint frequencies when $1 \mathrm{ml}$ or $5 \mathrm{ml}$ seawater was filtered

\begin{tabular}{|c|c|c|c|}
\hline \multirow{2}{*}{ Synechococcus } & \multicolumn{2}{|c|}{ Dry } & \multirow{2}{*}{$\begin{array}{l}\text { Wet } \\
5 \mathrm{ml}\end{array}$} \\
\hline & $1 \mathrm{ml}$ & $5 \mathrm{ml}$ & \\
\hline No. cells counted & 293 & 357 & 243 \\
\hline Abundance $\left(\mathrm{ml}^{-1}\right)$ & $7.18 \times 10^{4}$ & $6.19 \times 10^{4}$ & $3.99 \times 10^{4}$ \\
\hline Conjoint abundance $\left(\mathrm{ml}^{-1}\right)$ & $4.59 \times 10^{3}$ & $5.01 \times 10^{3}$ & $4.39 \times 10^{3}$ \\
\hline$\%$ conjoint & 6.4 & 8.1 & 11 \\
\hline
\end{tabular}

the idea that conjoint bacteria were an artifact of drying the sample on the filter (Table 3 ).

In conjunction with this experiment we also tested (as in a previous experiment) by EFM whether the frequency of conjoint Synechococcus-heterotrophic bacteria was a function of cell concentration on the filter ( 2 cells falling in such close proximity as to appear conjoint). We filtered $1 \mathrm{ml}$ and $5 \mathrm{ml}$ of a seawater sample, stained with DAPI (final concentration $1 \mathrm{\mu g} \mathrm{ml}^{-1}$; Table 3 ), and observed the samples by EFM. The percentages of conjoint bacteria in $1 \mathrm{ml}$ and in $5 \mathrm{ml}$ samples were comparable (Table 3 ). We recognize the difficulty of conclusively discarding the hypothesis of artifact formation due to sample manipulation, but the experiments failed to support this hypothesis. Nevertheless, throughout our discussion we have indicated caveats concerning the potential for artifact formation due to sample manipulation.

The occurrence of abundant symbioses or other spatially intimate interactions in the upper ocean has profound ecological, biogeochemical, and evolutionary implications and leads to new hypotheses on their diversity, nature, and functional significance. Syntrophic associations have been found in benthic marine systems (Boetius et al. 2000, Pernthaler et al. 2008). However, such associations have not previously been reported in the pelagic realm. In view of the large scale of the phenomenon reported here, it is likely that the physical associations reflect diverse types of ecological relationships including symbiosis, commensalism, antagonism, parasitism, or even incidental sticking upon bacteria-bacteria collisions in seawater. We have not attempted to investigate the nature of the relationships. However, in our images, we did not detect any gross morphological deterioration of one partner that might suggest one cell degrading the other cell, or one of the bacteria undergoing phage lysis, as was seen in an AFM-based study of cultured bacteria infected by viruses (Dubrovin et al. 2008).
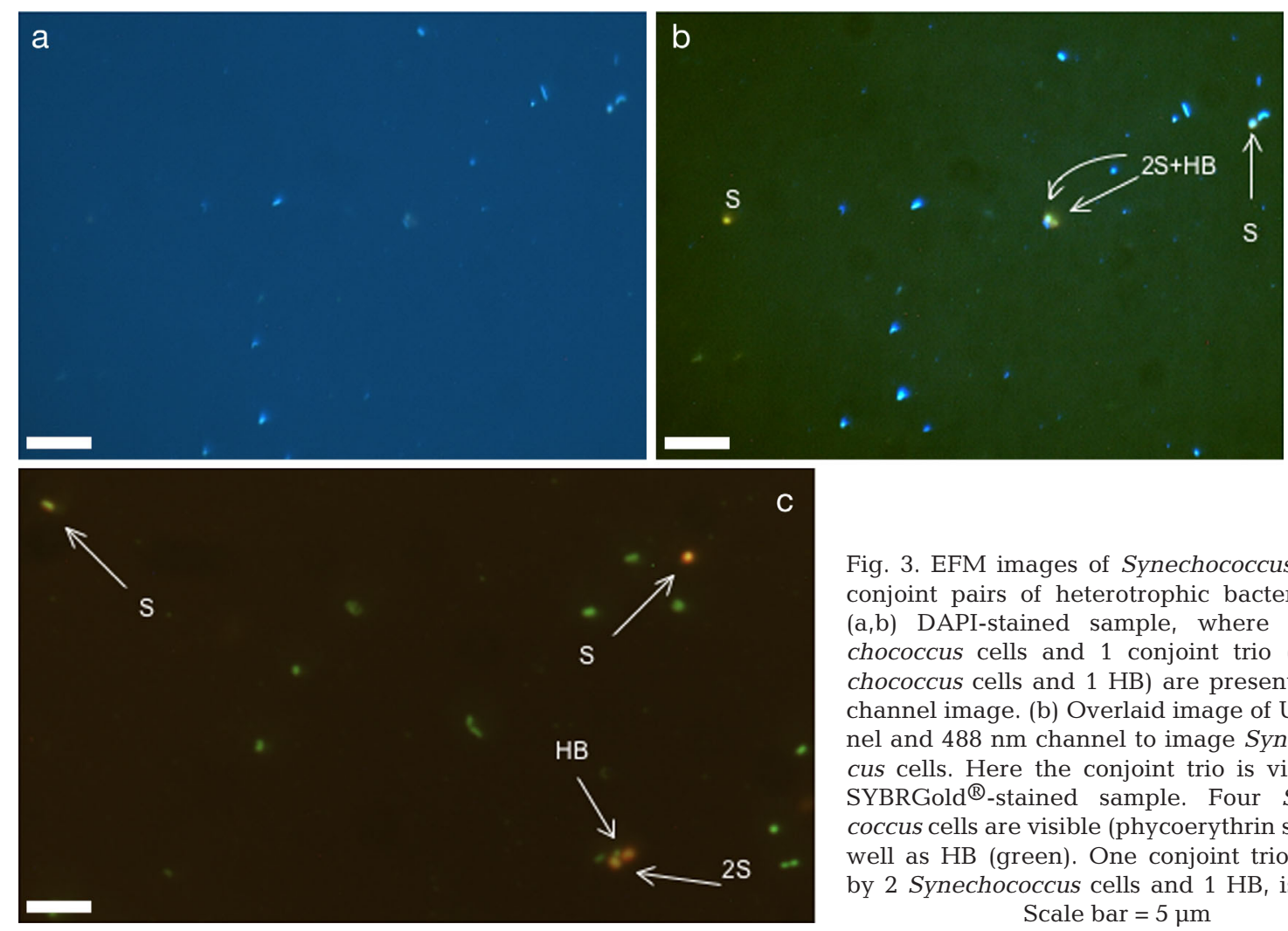

Fig. 3. EFM images of Synechococcus (S) and conjoint pairs of heterotrophic bacteria (HB). $(\mathrm{a}, \mathrm{b})$ DAPI-stained sample, where 3 Synechococcus cells and 1 conjoint trio (2 Synechococcus cells and $1 \mathrm{HB}$ ) are present. (a) UV channel image. (b) Overlaid image of UV channel and $488 \mathrm{~nm}$ channel to image Synechococcus cells. Here the conjoint trio is visible. (c) SYBRGold ${ }^{\circledR}$-stained sample. Four Synechococcus cells are visible (phycoerythrin signal) as well as HB (green). One conjoint trio, formed by 2 Synechococcus cells and $1 \mathrm{HB}$, is visible. Scale bar $=5 \mu \mathrm{m}$ 
A first step towards characterizing the nature and diversity of these possible symbioses would be to identify the conjoint partners, e.g. by combining fluorescent in situ hybridization (FISH) and AFM. A biogeochemically relevant prediction is that the conjoint heterotrophs coordinately enlarge their metabolic repertoires for utilizing polymers, nanoparticles, and complex organic matter, with implications for carbon cycling (Fig. 2a,b). The symbionts' genome sizes could be reduced where metabolic potentials are shared (Boetius et al. 2000, Huber et al. 2002). The enormous bacterial diversity in metagenomic surveys (Rusch et al. 2007 and references therein) and microdiversity in Vibrionacaea (Thompson et al. 2005) raised the question of diversity maintenance, and microscale patchiness has been proposed as an explanation. Such patchiness could in part be generated by symbioses (and bacterial networks; see 'Bacterial networks').

Over large spatial and temporal scales, Ruan et al. (2006), Fuhrman \& Steele (2008), and Fuhrman (2009) used global ocean biogeographical data to model bacterial communities as interaction networks. This allowed them to predict taxon-specific niche spaces and positive/negative relationships with other taxa and with environmental variables. They predicted the co-occurrence of specific taxa, possibly symbionts. Our findings support their prediction and further suggest conjoint bacteria as a mechanism of co-occurrence.

Synechococcus-bacteria associations could fundamentally influence the symbionts' microspatial nutrient status and growth physiology, and cause tight bacteriaPP coupling (particularly in mucus-enveloped associations, e.g. Fig. 2d). The heterotrophs would benefit by Synechococcus exudation, in turn supplying regenerated nutrients and growth factors. Prochlorococcus marinus growth is enhanced in co-culture with heterotrophic bacteria ('helper effect') as the heterotroph removes toxic reactive oxygen species (Morris et al. 2008). As a broader observation, microbial biogeochemistry generally considers bacteria-phytoplankton interactions in the context of bacteria and algae, but our findings suggest Synechococcus (and possibly Prochlorococcus, but these were not studied here) are also important microscale interaction loci for bacteria-phytoplankton interactions. Biogeochemical consequences of Synechococcusbacteria associations are particularly interesting because Synechococcus, as important primary producers, are abundant and essentially non-sinking cells.

\section{Bacterial networks}

High-resolution AFM further revealed another level of microspatial coupling. In most samples, substantial fractions of bacteria and Synechococcus cells, includ- ing some conjoint, were interconnected by fine pili or cell-surface gel matrices into pairs of associated bacteria or networks of 20 cells (Table 2, Fig. 4). Of the total bacteria imaged, $35 \%$ were within such pairs or networks (coastal 36\%, CCE $37 \%$, Antarctic 0\%). Networks were detected in most but not all seawater samples (coastal 14/18, CCE 1/2, Antarctic 0/2). Most of the heterotrophic bacteria and Synechococcus networks (48\%) consisted of 2 cell pairs; 3 cell networks accounted for $19 \%$, and $>5$ cell networks accounted for $14 \%$ (Fig. 5).

Fibril-mediated connections between bacteria, algae, and detritus were discovered by TEM in a study in the north Adriatic coastal waters (Heissenberger et al. 1996a). In a subsequent study, Heissenberger et al. (1996b) observed and proposed that the formation of microaggregates could be caused by capsular and fibrillar envelopes of bacteria. Our images suggest that generally, bacteria themselves produced cell surface architectures that served as the structural basis for the networks (rather than bacteria colonizing a pre-formed gel particle). In some instances, however, our images suggested that bacteria had colonized pre-formed microgels. Mechanisms of pelagic microgel (Svetlicic et al. 2005) formation include algal exocytosis (Chin et al. 2004), bacterial extracellular polysaccharides (EPS)-mediated polymer self organization of dissolved polymers (Ding et al. 2008), and organic matter self organization (Kerner et al. 2003, Engel et al. 2004). Bacterial expression of surface appendages as a strategy for association with surfaces or other organisms is well known. What is noteworthy here is a departure from the current ideas of the ecology of free and attached bacteria, they are based on pelagic bacteria examined by EFM but the connections and networks we report are not detected in EFM. Therefore, by EFM these bacteria; they are considered free-living. Our findings would therefore change how we think about the ecology of free and attached bacteria, and the role of bacteria in pelagic aggregations.

\section{Nanoparticle in bacterial networks}

Bacterial surface architecture can trap nanoparticles (Seo et al. 2007) and might be subjected to locally intense activities of ectohydrolases to convert them into directly usable substrates. We considered that bacterial networks might also capture a section of the organic matter continuum, thus exposing it to concerted metabolisms of bacteria comprising the network to generate dissolved organic matter hotspots. AFM images showed that bacterial networks (as well as bacterial surface architecture; Seo 
a

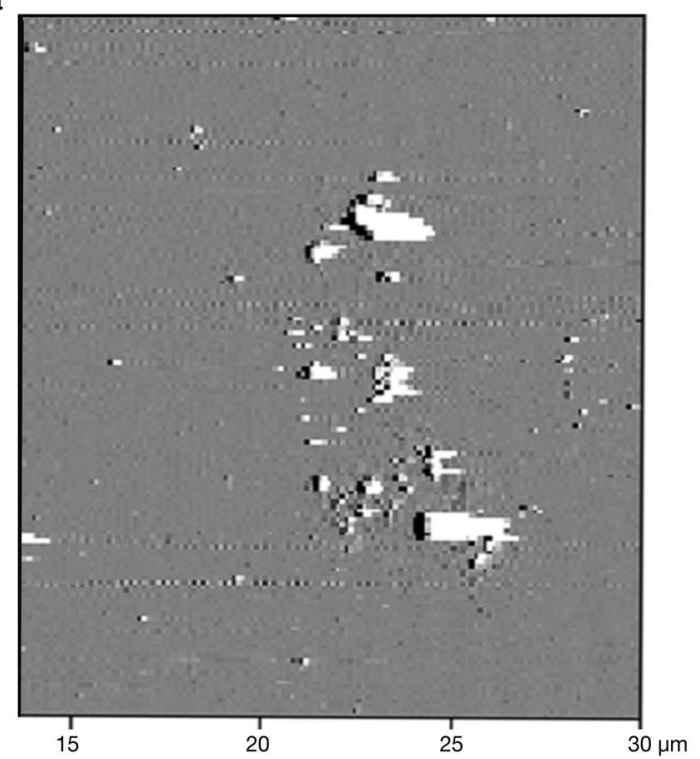

C

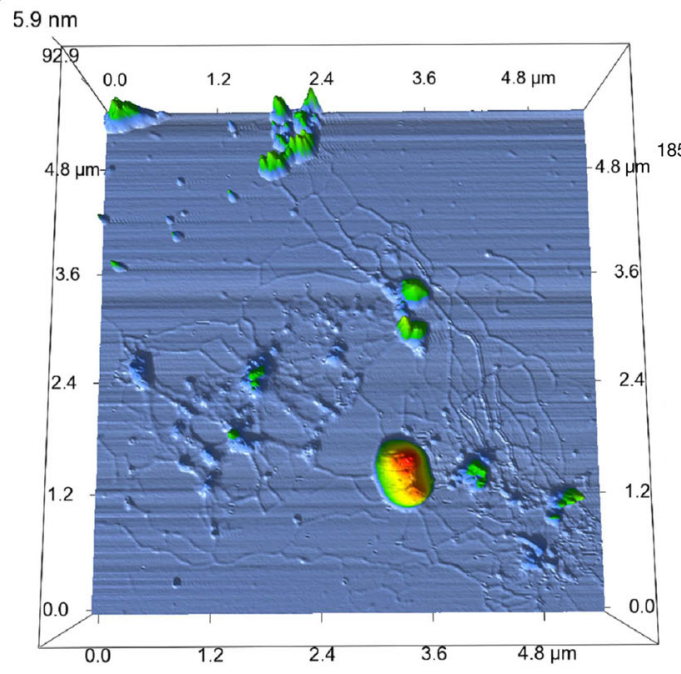

b

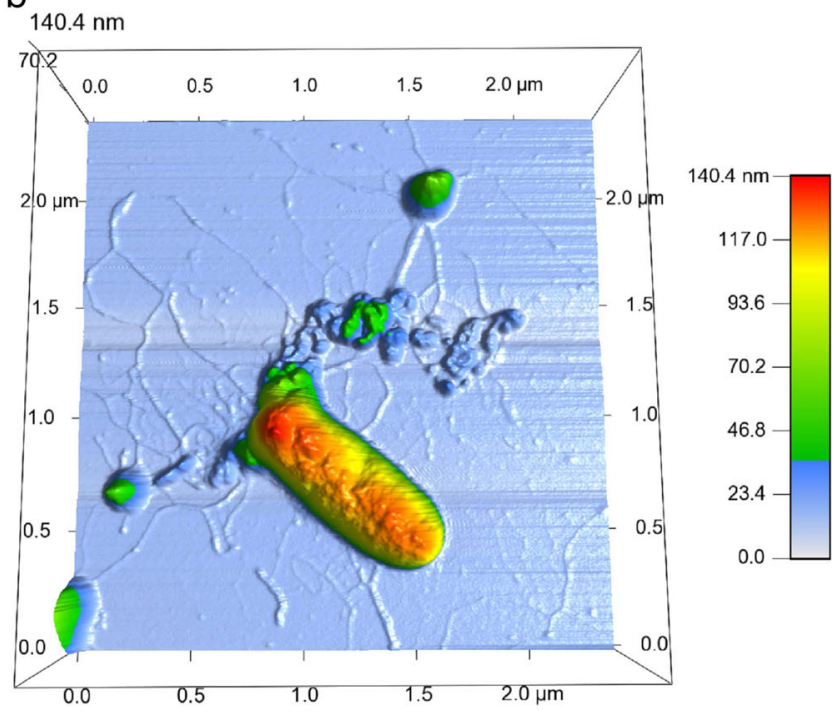

d

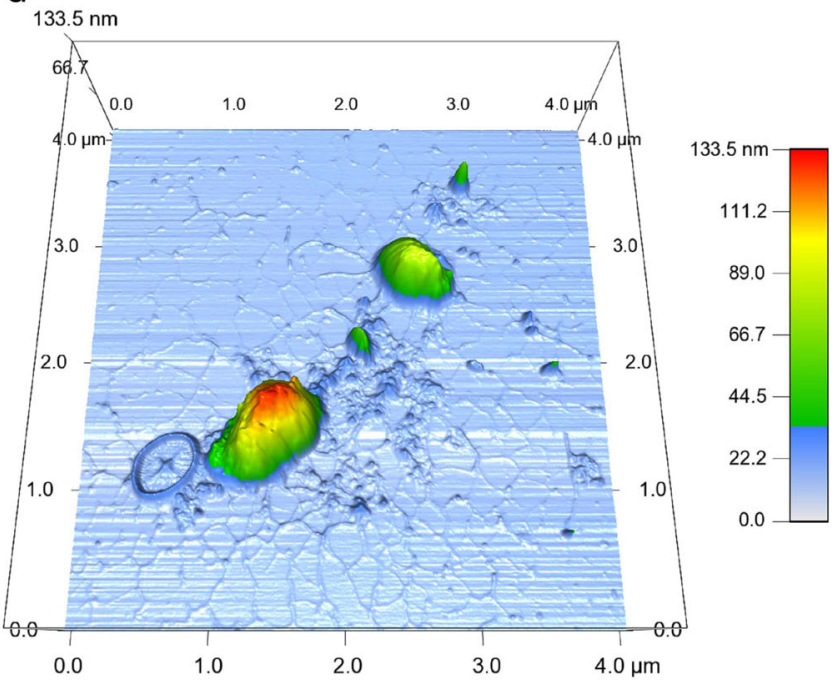

Fig. 4. Atomic force microscopy (AFM) images of bacterial networks. Seawater samples were collected from a coastal site (SIO) in April and August 2008 and from an offshore site during the CCE cruise at $53 \mathrm{~m}$ at Stn 206 in April 2007 (see Table 1). The height, $Z$, can be read as color on the color-coded scale or as number on the $z$-axis. (a) 2 -cell network that covers an area of $\sim 5 \times 10 \mu m$. The image was acquired in the Amplitude channel that lacks height information. The network is characterized by extensively branching long fibrils not visible in this low-resolution image. (b) Topographic close-up of the upper long rod cell in (a). The cell is surrounded by extensive fibrils. Nanometer-sized particles, $70-230 \mathrm{~nm}$, seem to emanate from the cell. Cell height is $140 \mathrm{~nm}$. (c) Topographic close-up of the lower rod cell in (a). The cell is within the extensive network that connects it with the upper cell in (b). Cell height is $139 \mathrm{~nm}$. (d) Topographic image of 2 heterotrophic bacteria (HB) connected by an extensive network. The upper and the lower cell are, respectively, 62 and $104 \mathrm{~nm}$ tall. The network occupies an area of $\sim 5 \times 5 \mu \mathrm{m}$. A coccolith (diameter $=589$ $\mathrm{nm}$; lower left) and nanometer-sized gel particles in the range of 60 to $300 \mathrm{~nm}$ are present in the network. (e) Topographic image of a 5 cell network. One large dividing cell (red, $Z=200 \mathrm{~nm}$ ) conjoint with a much smaller dividing cell (green, $Z=92 \mathrm{~nm}$; arrow 1). Also present in the network is a tiny cell (lower right, $Z=94 \mathrm{~nm}$; arrow 2). The network covers an area of $\sim 7 \times 7 \mu \mathrm{m}$. Fibrils are departing from both dividing pairs. A coccolith (diameter $=1 \mu \mathrm{m}$ ) and a diatom fragment are present within the network. (f) Transmitted light micrograph $(400 \times)$ of Synechococcus cells (circled) on mica from the offshore site (see Table 1). The large pointed shadow is the cantilever that carries the probe at a $90^{\circ}$ angle into the picture (therefore the probe is not visible here). $(\mathrm{g}$ ) Epifluorescence micrograph $(400 \times)$ of 2 Synechococcus cells (circled) from (f). Under 480 nm excitation phycoerythrin autofluoresces and thus allows the visualization of the Synechococcus cells. (h) Topographic image of the cells in (f) and (g). The 2 Synechococcus cells are connected with fibrils $(Z=1 \mathrm{~nm}$ ) and are associated with 3 conjoint HB (arrows 1-3). The upper and the lower Synechococcus cells are, respectively, 281 and $284 \mathrm{~nm}$ tall. From the top, the C-shaped HB is $85 \mathrm{~nm}$ tall (arrow 1), the coccoid cell conjoint with the upper Synechococcus cell is $92 \mathrm{~nm}$ tall (arrow 2), and the coccoid cell conjoint with the lower Synechococcus cell is $44 \mathrm{~nm}$ tall (arrow 3) 


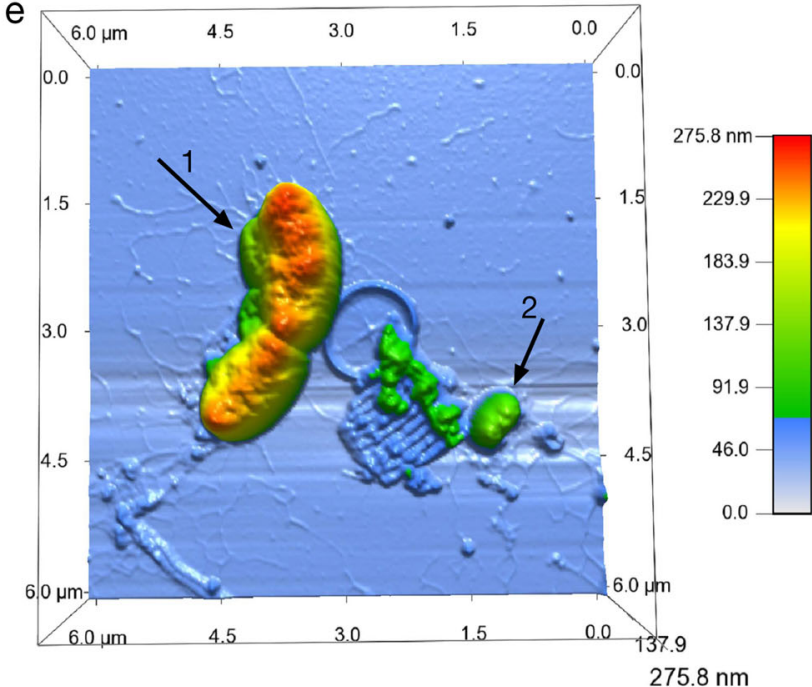

g

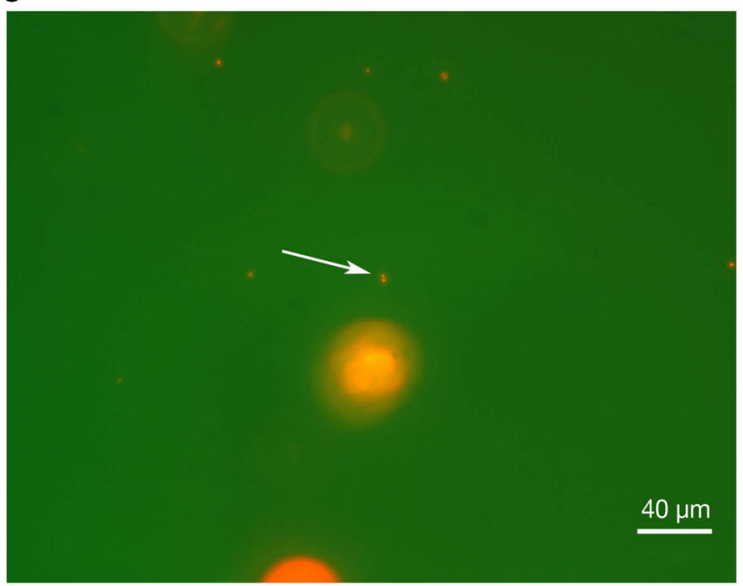

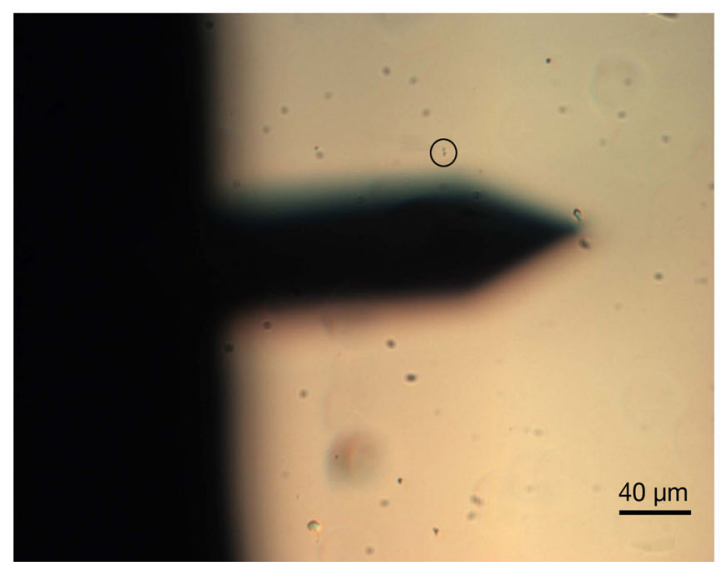

$\mathrm{h}$

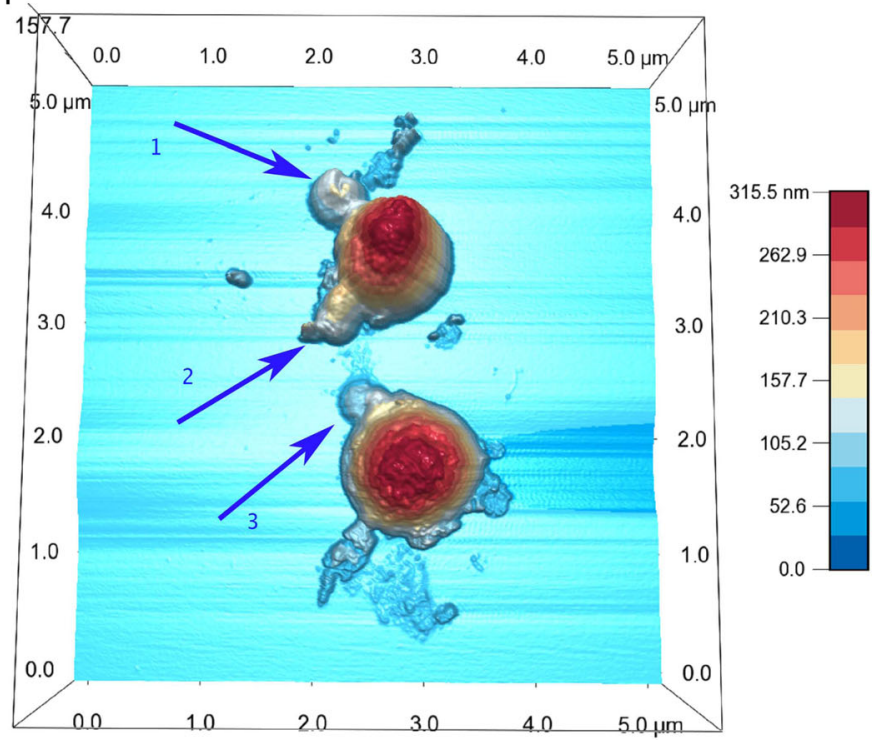

Fig 4 (continued)

et al. 2007) contained abundant structures tens to hundreds of nm in size (Figs. 1d, 2a-c,e,f, \& 4a-e), unattached gels, and 2 to $5 \mu \mathrm{m}$ long fibrils (Santschi et al. 1998). Further, viruses $\left(10^{7} \mathrm{ml}^{-1}\right.$ by EFM; not sized) were present in our samples. We could not resolve viruses from nanogels by AFM, but they were likely included in the nanoparticles. For example, in Fig. 1d, particles in the range of 50 to $300 \mathrm{~nm}$ present in Synechococcus cell surface architecture may well include viruses. Whether the cell has released these particles or whether they have been trapped into the network from seawater could not be determined. This also applies to Fig. 2e, where Synechococcus and the conjoint $\mathrm{C}$-shaped heterotrophic bacterium are surrounded by 50 to $200 \mathrm{~nm}$ particles. Also, we could not resolve whether bacterial networks are a source or a sink of nanoparticles in seawater. Further, phage adsorption to their host, or

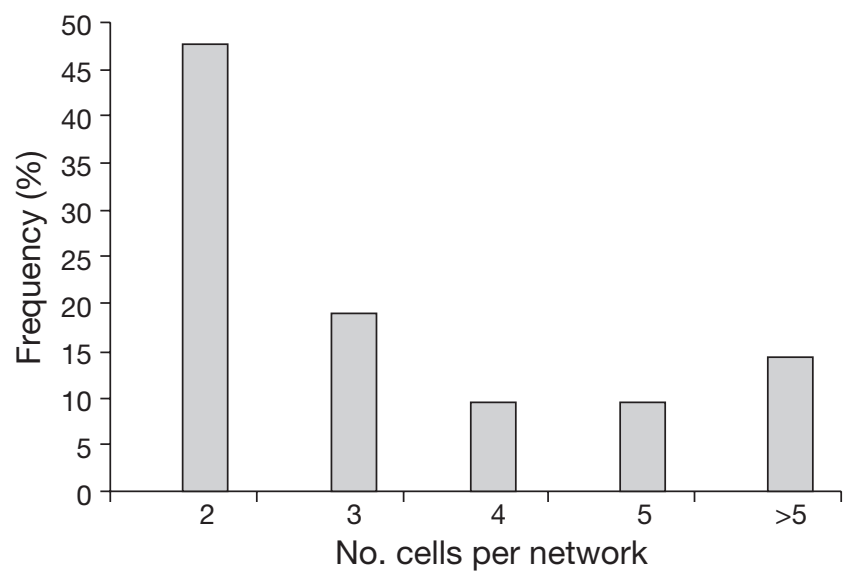

Fig. 5. Number of cells per network. Percentage frequency of the total number of cells in bacteria-bacteria and Synechococcus-bacteria networks. Here we combined the entire AFM image dataset 
phage release from the host, could create scenarios of the type we observed.

Bacterial networks may act as suspended biofilms. Indeed, one might speculate that traditional biofilms are an extensive expression of networks that bacteria form when they encounter and interact with a surface in the pelagic ocean. Such interactions would most commonly be with other bacteria and with nanogels and viruses. If so, then we should conceptualize biofilm formation as an adaptation to associate with other bacteria and colloids (rather than for colonizing non-living surfaces). Finally, the networks' fibrils might include nanowires (Reguera et al. 2005). This should be testable by conductive AFM.

\section{Coccoliths in bacterial networks?}

Interestingly, our AFM images showed coccoliths (314 $\mathrm{nm}$ to $1.67 \mu \mathrm{m}$, possibly derived from the families Rhabdosphaeraceae and Noelaerhabdaceae) as well as protist scales possibly derived from the genus Paraphysomonas seemingly trapped in bacterial networks (Fig. 3d,e). They might have an affinity for bacterial networks (Fig. 2c) since we rarely saw them free. However, it was not practical to make a quantitative comparison of attached and free coccoliths by AFM due to the large number of random fields that must be observed at high resolution. Coccoliths were also seen in larger aggregates that formed during a microcosm phytoplankton bloom (not shown). Coccolith capture into bacterial networks would cause a 'ballast effect' (Ziveri et al. 2007) due to high specific density $(2.7 \mathrm{~g}$ $\mathrm{cm}^{-3}$ ) of their calcite. Ballast materials, e.g. opal, calcite, and terrestrial dust, are often seen in marine snow, and they are important in accelerating export flux (Ploug et al. 2008).

Our observations suggest the hypothesis that because of their high abundance, large surface area, and potential for aggregation, bacterial networks scavenge ballast particles and serve as conduits for ballast acquisition by marine snow. Bacterial metabolism could modify the chemistry of the microenvironment (e.g. pH), thereby affecting coccolith dissolution. If ballast capture by bacterial networks is confirmed as a quantitatively significant process and found to occur widely in the ocean, it could be a variable in particle rain rate and carbon export.

\section{CONCLUSIONS}

Spatially intimate ecological relationships, whether positive or negative, as well as bacteria-bacteria networks were common among pelagic bacteria that had previously been considered by EFM to be dominated by 'solitary' and free-living bacteria. Such microspatial associations suggest a fundamentally new view of the environmental context in which pelagic bacteria act as a major biogeochemical force in the ocean. The discovery of abundant conjoint bacteria-bacteria and bacteria-Synechococcus opens up exciting research avenues on phylogenetic specificities, biochemical and molecular bases, adaptive significance, and biogeochemical influences of the implied relationships. Future studies on biogeochemical activity and adaptive biology (González et al. 2008) of pelagic bacteria need to deviate from the classical dichotomy of particle-attached and free-living lifestyles towards a unifying microspatial framework of genetically diverse assemblages dynamically interacting with organisms (mostly microbes) and the organic matter continuum. Climate change and ocean acidification could alter the microspatial architecture and bacterial interactions, with feedback to the ocean carbon cycle. Predicting the outcomes requires a convergence of biochemical and genomic approaches with fundamental insights that can further be gained by the study of microbial biogeochemistry as a microspatial structural problem.

Acknowledgements. We thank J. T. Samo, M. Manganelli, J. Ward, E. Kisfaludy, and C. Dupont for kindly providing the offshore samples from the BWZ II cruise 2006 in Antarctica, CCE-LTER Process Cruise 2007, EK 2008, and Socerer II 2008. We thank J. McGowan for advice and insight on the coherence between SIO pier and CCE biogeochemistry. We thank Asylum Research staff for their help and support with AFM. Chlorophyll and temperature data were retrieved from the SCCOOS data archive website supported by NOAA, and from the CCE-LTER data archive website supported by the Division of Ocean Sciences, NSF. We thank B. Palenik, B. Brahamsha, and S. Sandin for their valuable comments and suggestions. This research was supported by the Gordon and Betty Moore Foundation Marine Microbiology Initiative and NSF grants 0648116 and 0428900 to F.A.

\section{LITERATURE CITED}

Amro NA, Kotra LP, Wadu-Mesthrige $K$, Bulychev A, Mobashery S, Liu G (2000) High-resolution atomic force microscopy studies of the Escherichia coli outer membrane: structural basis for permeability. Langmuir 16: $2789-2796$

Azam F (1998) Microbial control of oceanic carbon flux: the plot thickens. Science 280:694-696

Azam F, Malfatti F (2007) Microbial structuring of marine ecosystems. Nat Rev Microbiol 5:782-791

Balnois E, Wilkinson KJ (2002) Sample preparation techniques for the observation of environmental biopolymers by atomic force microscopy. Colloids Surf A Physicochem Eng Asp 207:229-242

Beveridge TJ, Graham LL (1991) Surface layers of bacteria. Microbiol Mol Biol Rev 55:684-705

Binnig G, Quate CF (1986) Atomic force microscopy. Phys Rev Lett 56:930-933 
Boetius A, Ravenschlag K, Schubert CJ, Rickert D and others (2000) A marine microbial consortium apparently mediating anaerobic oxidation of methane. Nature 407:623-626

Chin WC, Orellana MV, Verdugo P (1998) Spontaneous assembly of marine dissolved organic matter into polymer gels. Nature 391:568-572

Chin WC, Orellana MV, Quesada I, Verdugo P (2004) Secretion in unicellular marine phytoplankton: demonstration of regulated exocytosis in Phaeocystis globosa. Plant Cell Physiol 45:535-542

Costerton JW, Irvin RT, Cheng KJ (1981) The bacterial glycocalyx in nature and disease. Annu Rev Microbiol 35: 299-324

$>$ De Momi A, Lead JR (2008) Behaviour of environmental aquatic nanocolloids when separated by split-flow thincell fractionation (SPLITT). Sci Total Environ 405:317-323

del Giorgio PA, Williams PJ (2005) The global significance of respiration in aquatic ecosystems: from single cells to the biosphere. In: del Giorgio PA, Williams, PJ (eds) Respiration in aquatic ecosystems. Oxford University Press, New York, p 2667-2273

> Ding YX, Chin WC, Rodriguez A, Hung CC, Santschi PH, Verdugo P (2008) Amphiphilic exopolymers from Sagittula stellata induce DOM self-assembly and formation of marine microgels. Mar Chem 112:11-19

Dubrovin EV, Voloshin AG, Kraevsky SV, Ignatyuk TE, Abramchuk SS, Yaminsky IV, Ignatov SG (2008) Atomic force microscopy investigation of phage infection of bacteria. Langmuir 24:13068-13074

Ducklow HW (2000) Bacteria production and biomass in the oceans. In: Kirchman DL (ed) Microbial ecology of the oceans. Wiley-Liss, New York, p 85-120

> Dufrêne YF (2008a) Atomic force microscopy and chemical force microscopy of microbial cells. Nat Protoc 3: 1132-1138

> Dufrêne YF (2008b) Towards nanomicrobiology using atomic force microscopy. Nat Rev Microbiol 6:674-680

Engel A, Thoms S, Riebesell U, Rochelle-Newall E, Zondervan I (2004) Polysaccharide aggregation as a potential sink of marine dissolved organic carbon. Nature 428: 929-932

Fuhrman JA (2009) Microbial community structure and its functional implications. Nature 459:193-199

Fuhrman JA, Steele JA (2008) Community structure of marine bacterioplankton: patterns, networks, and relationships to function. Aquat Microb Ecol 53:69-81

- González JM, Fernández-Gómez B, Fernández-Guerra A, Gómez-Consarnau L and others (2008) Genome analysis of the proteorhodopsin-containing marine bacterium Polaribacter sp. MED152 (Flavobacteria). Proc Natl Acad Sci USA 105:8724-8729

> Heissenberger A, Leppard G, Herndl G (1996a) Ultrastructure of marine snow. II. Microbiological considerations. Mar Ecol Prog Ser 135:299-308

> Heissenberger A, Leppard GG, Herndl GJ (1996b) Relationship between the intracellular integrity and the morphology of the capsular envelope in attached and free-living marine bacteria. Appl Environ Microbiol 62:4521-4528

Hewes CD, Holm-Hansen O (1983) A method for recovering nanoplankton from filters for identification with the microscope: the filter-transfer-freeze (FTF) technique. Limnol Oceanogr 28:389-394

- Holm-Hansen O, Riemann B (1978) Chlorophyll a determination: improvements in methodology. Oikos 30:438-447

Huber H, Hohn MJ, Rachel R, Fuchs T, Wimmer VC, Stetter KO (2002) A new phylum of Archaea represented by a nanosized hyperthermophilic symbiont. Nature 417:63-67
Johnson PW, Sieburth JM (1982) In-situ morphology and occurrence of eucaryotic phototrophs of bacterial size in the picoplankton of estuarine and oceanic waters. J Phycol 18:318-327

Kerner M, Hohenberg H, Ertl S, Reckermann M, Spitzy A (2003) Self-organization of dissolved organic matter to micelle-like microparticles in river water. Nature 422: $150-154$

Kim HJ (2008) Climate impacts on the planktonic marine ecosystem in the Southern California current. UCSD, La Jolla, CA

Koike I, Hara S, Terauchi K, Kogure K (1990) The role of submicron particles in the ocean. Nature 345:242-244

Leppard GG, West MM, Flannigan DT, Carson J, Lott NAJ (1997) A classification scheme for marine organic colloids in the Adriatic Sea: colloid speciation by transmission electron microscopy. Can J Fish Aquat Sci 54:2334-2349

> Lienemann CP, Heissenberger A, Leppard GG, Perret D (1998) Optimal preparation of water samples for the examination of colloidal material by transmission electron microscopy. Aquat Microb Ecol 14:205-213

Mangold S, Harneit K, Rohwerder T, Claus G, Sand W (2008) Novel combination of atomic force microscopy and epifluorescence microscopy for visualization of leaching bacteria on pyrite. Appl Environ Microbiol 74:410-415

McCarren J, Heuser J, Roth R, Yamada N, Martone M, Brahamsha B (2005) Inactivation of swmA results in the loss of an outer cell layer in a swimming Synechococcus strain. J Bacteriol 187:224-230

McGowan JA, Cayan DR, Dorman LM (1998) Climate-ocean variability and ecosystem response in the Northeast Pacific. Science 281:210-217

Moran MA, Belas R, Schell MA, Gonzalez JM and others (2007) Ecological genomics of marine roseobacters. Appl Environ Microbiol 73:4559-4569

Morris JJ, Kirkegaard R, Szul MJ, Johnson ZI, Zinser ER (2008) Robust growth of Prochlorococcus colonies and dilute liquid cultures: facilitation by 'helper' heterotrophic bacteria. Appl Environ Microbiol 74:4530-4534

Nagata T (2008) Organic matter-bacteria interactions in seawater. In: Kirchman DL (ed) Microbial ecology of the oceans. John Wiley \& Sons, Hoboken, NJ, p 207-241

> Nishino T, Ikemoto E, Kazuhiro K (2004) Application of atomic force microscopy to observation of marine bacteria. J Oceanogr 60:219-225

> Palenik B, Ren Q, Dupont CL, Myers GS and others (2006) Genome sequence of Synechococcus CC9311: insights into adaptation to a coastal environment. Proc Natl Acad Sci USA 103:13555-13559

Pernthaler A, Dekas AE, Brown CT, Goffredi SK, Embaye T, Orphan VJ (2008) Diverse syntrophic partnerships from deep-sea methane vents revealed by direct cell capture and metagenomics. Proc Natl Acad Sci USA 105: 7052-7057

Ploug H, Iversen M, Koski M, Buitenhuis E (2008) Production, oxygen respiration rates, and sinking velocity of copepod fecal pellets: direct measurements of ballasting by opal and calcite. Limnol Oceanogr 53:469-476

Pomeroy LR, Williams PJL, Azam F, Hobbie JE (2007) The microbial loop. Oceanography (Wash DC) 20:28-33

> Reguera G, McCarthy KD, Mehta T, Nicoll JS, Tuominen MT, Lovley DR (2005) Extracellular electron transfer via microbial nanowires. Nature 435:1098-1101

> Ritter C, Heyde M, Schwarz UD, Rademann K (2002) Controlled translational manipulation of small latex spheres by dynamic force microscopy. Langmuir 18:7798-7803

Ruan Q, Steele JA, Schwalbach MS, Fuhrman JA, Sun F 
(2006) A dynamic programming algorithm for binning microbial community profiles. Bioinformatics 22: 1508-1514

Rusch DB, Halpern AL, Sutton G, Heidelberg KB and others (2007) The Sorcerer II global ocean sampling expedition: Northwest Atlantic through Eastern Tropical Pacific. PLoS Biol 5:e77

Santschi PH, Balnois E, Wilkinson KJ, Zhang J, Buffle J, Guo L (1998) Fibrillar polysaccharides in marine macromolecular organic matter as imaged by atomic force microscopy and transmission electron microscopy. Limnol Oceanogr 43:896-908

Seo Y, Eiko I, Akihiro Y, Kazuhiro K (2007) Particle capture by marine bacteria. Aquat Microb Ecol 49:243-253

Sieburth JM (1975) Microbial seascape. A pictorial essay on marine microorganisms and their environments. University Park Press, Baltimore, MD

Stukalov O, Korenevsky A, Beveridge TJ, Dutcher JR (2008) Use of atomic force microscopy and transmission electron microscopy for correlative studies of bacterial capsules. Appl Environ Microbiol 74:5457-5465

Editorial responsibility: Fereidoun Rassoulzadegan, Villefranche-sur-Mer, France
Svetličić V, Žutić V, Hozić Zimmermann A (2005) Biophysical scenario of giant gel formation in the northern Adriatic Sea. Ann N Y Acad Sci 1048:524-527

Thompson JR, Pacocha S, Pharino C, Klepac-Ceraj V and others (2005) Genotypic diversity within a natural coastal bacterioplankton population. Science 307:1311-1313

Vadillo-Rodriguez V, Beveridge TJ, Dutcher JR (2008) Surface viscoelasticity of individual Gram-negative bacterial cells measured using atomic force microscopy. J Bacteriol 190:4225-4232

Verdugo P, Alldredge AL, Azam F, Kirchman DL, Passow U, Santschi PH (2004) The oceanic gel phase: a bridge in the DOM-POM continuum. Mar Chem 92:67-85

Williams PJLeB (2005) Microbial production and the decomposition of organic material. In: Kaiser D, Attrill M, Jennings S, Thomas DN and others (eds) Marine ecology: processes, systems and impacts. Oxford University Press, New York, p 584

Ziveri P, de Bernardi B, Baumann KH, Stoll HM, Mortyn PG (2007) Sinking of coccolith carbonate and potential contribution to organic carbon ballasting in the deep ocean. Deep-Sea Res II 54:659-675

Submitted: April 14, 2009; Accepted: July 13, 2009 Proofs received from author(s): November 11, 2009 